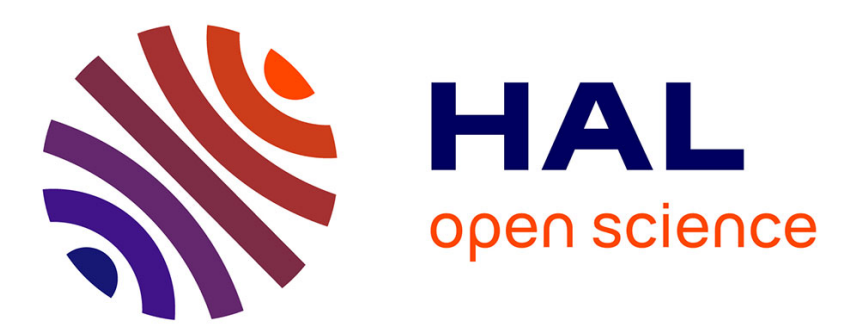

\title{
A 1961-2010 record of fertilizer use, pesticide application and cereal yields: a review
}

Yongbo Liu, Xubin Pan, Junsheng Li

\section{To cite this version:}

Yongbo Liu, Xubin Pan, Junsheng Li. A 1961-2010 record of fertilizer use, pesticide application and cereal yields: a review. Agronomy for Sustainable Development, 2015, 35 (1), pp.83-93. 10.1007/s13593014-0259-9 . hal-01284272

\section{HAL Id: hal-01284272 \\ https://hal.science/hal-01284272}

Submitted on 7 Mar 2016

HAL is a multi-disciplinary open access archive for the deposit and dissemination of scientific research documents, whether they are published or not. The documents may come from teaching and research institutions in France or abroad, or from public or private research centers.
L'archive ouverte pluridisciplinaire HAL, est destinée au dépôt et à la diffusion de documents scientifiques de niveau recherche, publiés ou non, émanant des établissements d'enseignement et de recherche français ou étrangers, des laboratoires publics ou privés. 


\title{
A 1961-2010 record of fertilizer use, pesticide application and cereal yields: a review
}

\author{
Yongbo Liu • Xubin Pan • Junsheng Li
}

Accepted: 3 October 2014 / Published online: 30 October 2014

(C) INRA and Springer-Verlag France 2014

\begin{abstract}
Global crop production has doubled since the Green Revolution on the average, but crop yield has stagnated or even declined in some regions. In the same time, food demand has highly increased due to population growth and higher living standards. The use of pesticides and mineral fertilizers has improved crop yields but also contaminated food and the environment, thus leading to a global food crisis. Here, we reviewed the historical trends of global pesticide and fertilizer application, cereal yields, and production. Our main findings are as follows: (1) fertilizer and pesticide consumption increased for 35-40 \% of the countries; (2) cereal production in $38 \%$ of countries and yields in $47 \%$ of countries either stagnated or decreased from 1961 to 2010; (3) countries showing stagnated or decreased yields are countries with low gross domestic product per capita, mainly situated in Africa, South America, and West Asia. Our findings thus evidence a global imbalance in food production and the usage of fertilizers and pesticides.
\end{abstract}

Keywords Consumption imbalance $\cdot$ Fertilizers $\cdot$ Pesticides · Cereal production $\cdot$ Environmental protection

\section{Contents}

1. Introduction . .4

2. History trend of global fertilizer consumption. 6

Y. Liu $(\bowtie) \cdot \operatorname{J.} \operatorname{Li}(\bowtie)$

State Key Laboratory of Environmental Criteria and Risk Assessment, Chinese Research Academy of Environmental Sciences, 8 Dayangfang, 100012 Beijing, China e-mail: liu.yongbo@yahoo.com

e-mail: lijsh@craes.org.cn

\section{Pan}

Institute of Plant Quarantine, Chinese Academy of Inspection and Quarantine, 100029 Beijing, China
3. History trend of global pesticide consumption ............. 9

3.1 Insecticide consumption .................................... 9

3.2 Herbicide consumption ................................... 10

3.3 Fungicide and bactericide consumption .............. 11

4. History trend of global cereal yields and produc-

tion ....................................................................... 13

4.1 Yield of total cereals ........................................ 13

4.2 Production of total cereals .................................. 14

5. Integrated assessment of chemical additions ................ 16

6. Conclusions .............................................................. 19

\section{Introduction}

Increased global crop production has decreased the number of hungry people worldwide since the Green Revolution (Godfray et al. 2010). However, in 2010, there were still 925 million undernourished people worldwide, with $98 \%$ of these individuals living in developing countries (FAO 2010). Crop yields have stagnated or even declined in some regions (Peltonen-Sainio et al. 2009; Lin and Huybers 2012), and cereal yields in around a quarter of cereal growing area did not improve from 1961 to 2008 (Ray et al. 2012). This indicates a potential global food crisis in the coming decades, which will likely be aggravated by a decrease in the area in agricultural production (Foley et al. 2011; Graf et al. 2014), the continual expansion of biofuel production (Gelfand et al. 2013), generally elevated standards of living, and huge food wastage (Del Grosso and Cavigelli 2012). The crisis may be serious (Fig. 1), not only in relatively poor countries but also in countries that depend on food imports; if food-exporting countries stop exporting or increase food prices, then countries that depend on food imports will require increased domestic food production, likely through increased fertilizers and pesticides usage.

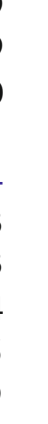




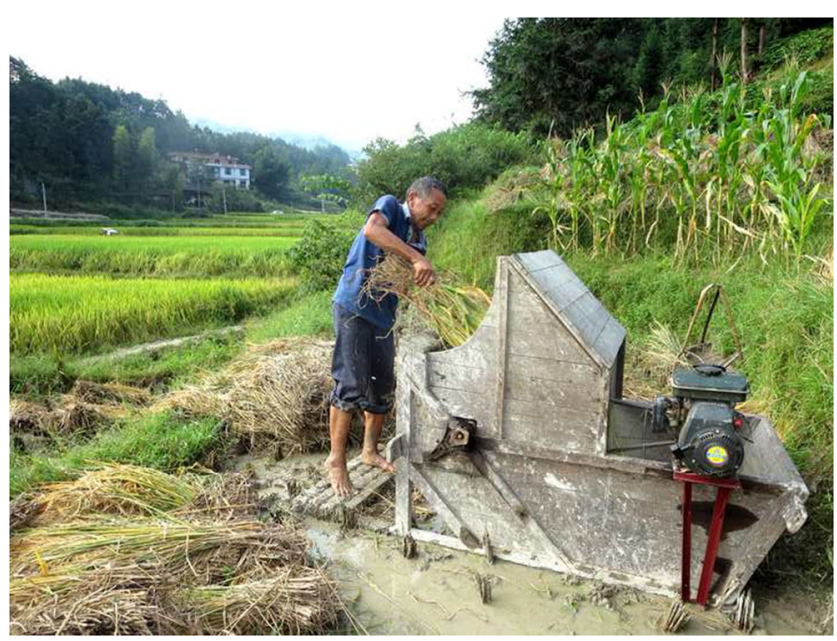

Fig. 1 Rice harvesting in a village, Hunan Province, China

Application of chemical fertilizers and pesticides in agricultural systems has increased in the past decades as a means for improving crop yields (Fig. 2), and application has been predicted to continue to increase substantially in the next few decades (Matson et al. 1997; Tilman et al. 2002; Mueller et al. 2012; Martínez-Blanco et al. 2013). However, the use of these chemicals is controversial because of their environmental impacts (Garratt et al. 2011; Gill et al. 2012; Henry et al. 2012; Whitehorn et al. 2012; Popp et al. 2013; Pelosi et al. 2014). Pesticides significantly reduced the biodiversity of stream invertebrates in Europe and Australia and resulted in a loss of $42 \%$ species pools (Beketov et al. 2013). Agricultural non-point source pollution has been common in developing countries and is induced by excessive inputs of nutrients (Sun et al. 2012). The debate continues over the effects of these additions on the sustainability of the food supply and public and ecosystem health (Liu et al. 2012; Pingali 2012). Moreover, imbalance in chemical additions in agricultural production is common because national policies and/or regional resources are different (Vitousek et al. 2009; MacDonald et al. 2011). Phosphorus scarcity is widespread in South America while most of Eastern Asia has a phosphorus surplus (MacDonald et al. 2011). Similarly, $80 \%$ of African countries are nitrogen deficient, while nitrogen surpluses are common in most Asian countries (Ju et al. 2009; Vitousek et al. 2009; Liu et al. 2010). Surplus nutrients are lost to natural ecosystems through leaching, soil erosion, and gas production, which degrade water and air quality (Ju et al. 2009).

In this study, we, thus, analyzed both the historical trends and current status of global pesticide and fertilizer application, cereal yields and production, and per capita cereal production, in order to make suggestions as to which countries need to increase fertilizer and pesticide application to improve crop production and which need to decrease chemical applications for environmental protection. This can assist countries in applying policy actions to reach a balance between food supply and environmental protection, in the face of global imbalances in resource consumption.

\section{History trend of global fertilizer consumption}

From the IFADATA website (IFA 2012), consumption data were obtained for total global $\mathrm{N}+\mathrm{P}_{2} \mathrm{O}_{5}+\mathrm{K}_{2} \mathrm{O}$ as fertilizer from 1961 to 2010. A total of 88 countries with relatively complete data were used for trend analysis of fertilizer consumption. The 88 countries under study consumed 110 million tonnes of fertilizers (nitrogen, phosphate, and potash) per year on average from 1961 to 2010 (IFA 2012). China consumed the most fertilizer using, 21.6 million tonnes each year, followed by the USA (Table 1). Eighteen countries used more than 1 million tonne of fertilizer each country per year on average. Fertilizer application rates, as fertilizer consumption per hectare of harvested area, were not even across the global. There 15 countries were lacking in fertilizer, using less than $50 \mathrm{~kg} \mathrm{ha}^{-1}$ in 2010, approximately $73 \%$ of these countries (11 countries) situated in Africa (Fig. 3). In contrast, Mauritius, New Zealand, Malaysia, Ireland, Kuwait, Netherlands, Israel, and Chile consumed more than $800 \mathrm{~kg}$ fertilizers per hectare of harvested area in 2010 (Fig. 3). Those countries and regions, both developed and developing, that typically use an excess of chemical fertilizers should reduce
Fig. 2 Pesticide application in a research base on plant protection, Nanjing, China

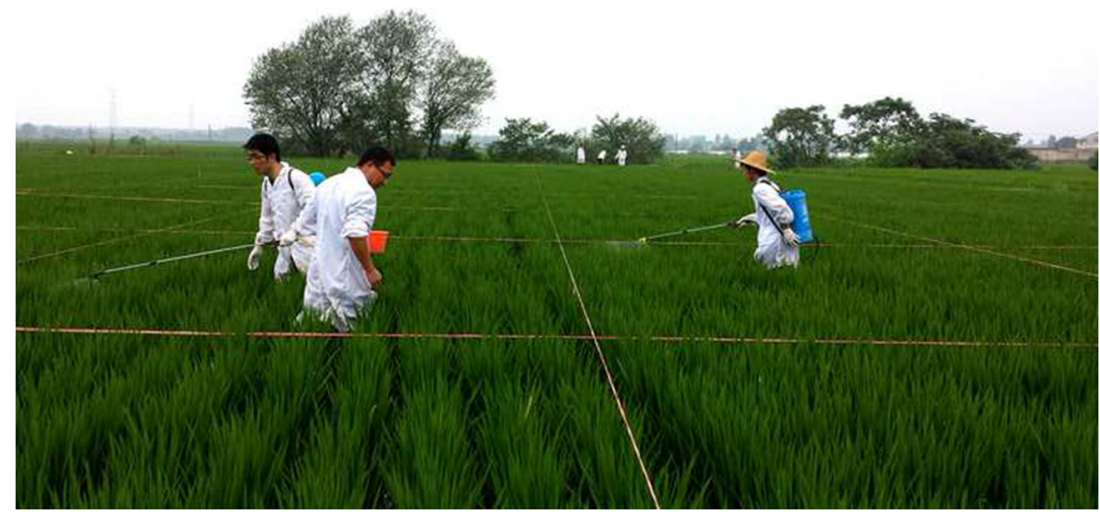




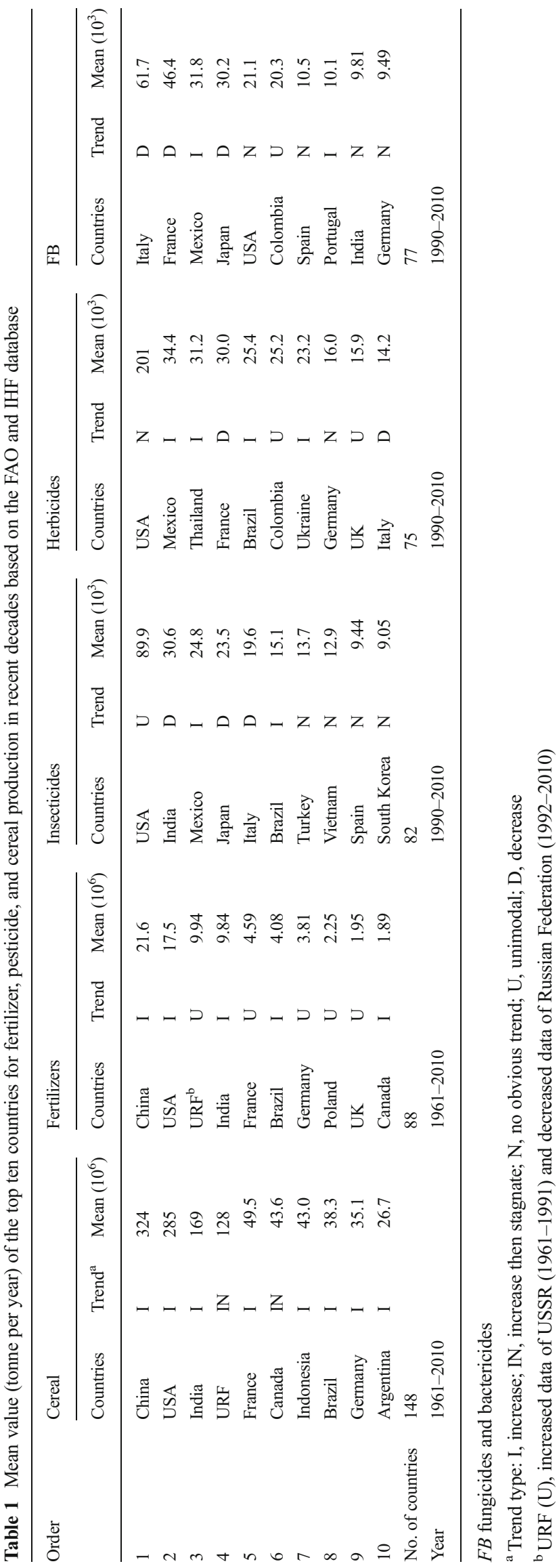

inputs and take measures to increase the efficiency of chemical additions, for the benefit of the agricultural economy, the environment, and human health (Gill et al. 2012; Henry et al. 2012; Kuivila et al. 2012; Whitehorn et al. 2012). Scarcity of nutrient supplies is also a key factor that limited the increase in cereal yields (Vitousek et al. 2009; Liu et al. 2010; MacDonald et al. 2011). These developing countries first need to feed their increasing human populations. Modern technologies and best practices could help developing nations to increase crop production substantially. For example, in Africa, the lack of roads makes it way too expensive and difficult for farmers to get access to synthetic fertilizers, which hampers agricultural productivity.

Based on the observed trends in fertilizer consumption, the countries and regions were categorized into five groups (Ray et al. 2012): increasing (I-style), interannual variation but no obvious trends (N-style), first increasing and then stagnating (IN-style), first increasing and then decreasing with a unimodal trend (U-style), and finally decreasing over time (D-style). Fertilizer consumption in 35 countries (39.7\%) increased (I-style) over the study period (Fig. 4; Table 2); this category included only three developed countries with the majority situated in Asia and South America. There were 15 IN-style countries (17.1\%) (Fig. 4), including the USA and Spain, two developed countries. Seven countries were categorized as N-style (7.95\%). Thirty countries (34.1\%) exhibited the U-style, first increasing and then decreasing, and most of these (21 countries) were developed nations situated in Europe. There was only one D-style country (Trinidad and Tobago), which consumed a decreasing quantity of fertilizer from 1961 to 2010 (Fig. 4). Some developed countries have decreased their consumption of fertilizers and pesticides in recent years owing to growing public concern over the environmental impacts of excessive chemical inputs in agriculture systems (Ju et al. 2009; MacDonald et al. 2011; Sun et al. 2012). In contrast, research agendas and national policy should be focused on the needs of resource-limited countries. Multiple non-governmental organizations (NGOs) are pouring money to African farmers to providing fertilizers. Some African countries show recent increases in consumption. Agricultural policies provide farm households with grains and input subsidies in developing nations made them to use enough chemical applications (Huang et al. 2011).

Thousands of tonnes of fertilizers have been consumed to improve crop yield since the Green Revolution beginning a few decades ago (Tilman 2001; Mueller et al. 2012). However, harvested crops generally only consume about half of the fertilizer input to a given fields (Liu et al. 2010; Miao et al. 2011); the excess fertilizer is a threat to the surrounding environment and a large waste for farmers. Fertilizers affect soil organic carbon by influencing crop residue and $\mathrm{C}$ mineralization (e.g., Russell et al. 2009; Martínez-Blanco et al. 2013). Eutrophication of surface waters, particularly in

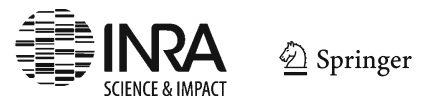




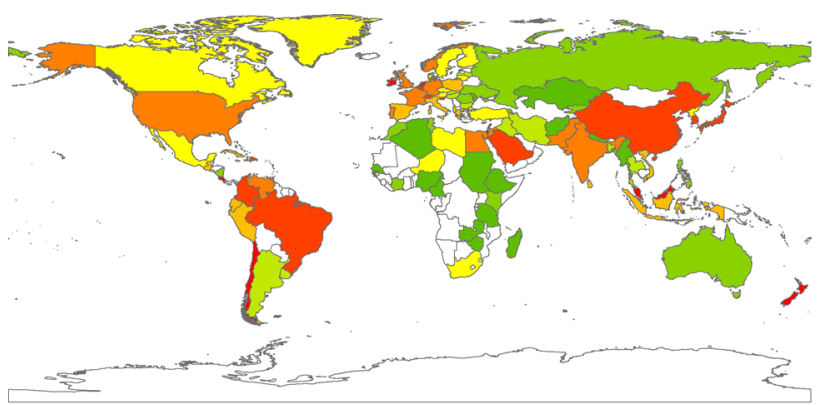

Fertilizer rate $(\mathrm{Kg} / \mathrm{ha})$ in 2010

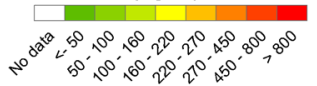

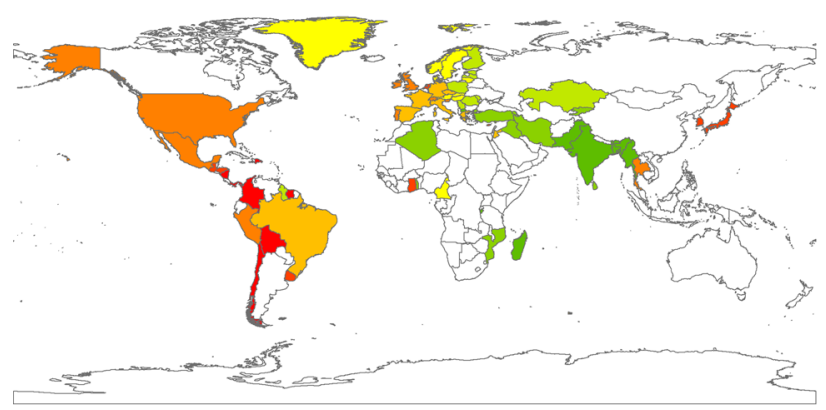

Herbicide rate $(\mathrm{g} / \mathrm{ha})$ in 2010

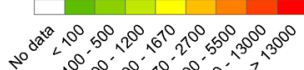

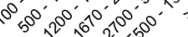

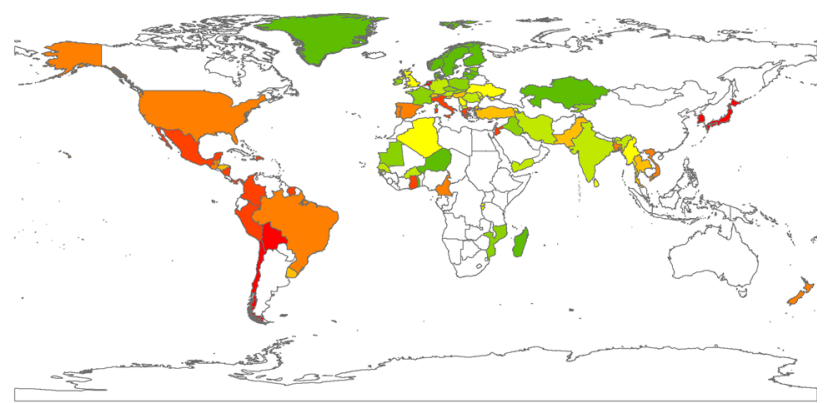

Insecticide rate $(\mathrm{g} / \mathrm{ha})$ in 2010

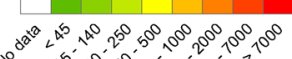

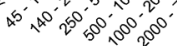

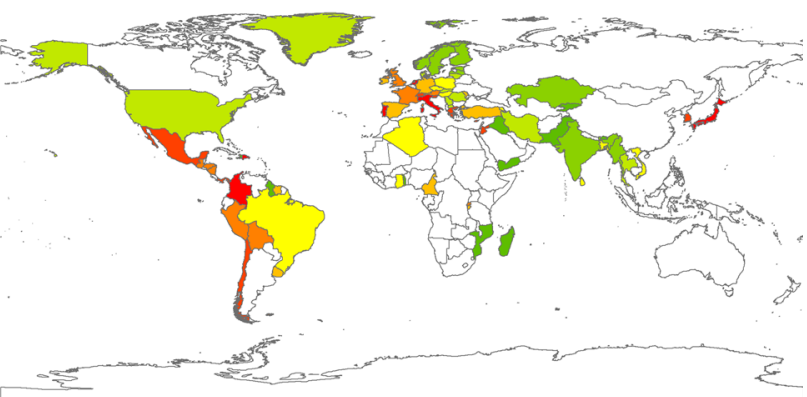

FB rate $(g / h a)$ in 2010

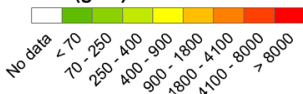

Fig. 3 Global maps of consumption rate for chemical additions in 2010. Top left, fertilizer rate; top right, insecticide rate; bottom left, herbicide rate; bottom right, rate of fungicide and bactericide

freshwater streams and coastal seas, the degradation of downstream water quality, loss of biodiversity and changes in species composition, tropospheric smog and ozone production, and acidification of soils are major environmental consequences of fertilizer additions (Vitousek et al. 1997, 2009; Carpenter et al. 1998). FAO through the global soil partnership has provided useful soil information for agricultural management, including how to select crop species and determine irrigation and fertilizer or other inputs, etc. (Omuto et al. 2013).

\section{History trend of global pesticide consumption}

A database on global pesticide consumption, including insecticides, herbicides, fungicides, and bactericides, from 1990 to 2010 was obtained from the FAOSTAT website (FAO 2012). There are 81,75 , and 77 countries that had relatively complete databases allowing for the detection of trends in pesticide consumption for insecticides, herbicides, and fungicides and bactericides, respectively. Data from the USSR (former FSU) and from the Russian Federation were combined as the URF. Former Czechoslovakia and the Czech Republic were combined as "Czech." Pesticide consumption was analyzed from
1990 to 2010 worldwide and included insecticides, herbicides, fungicides, and bactericides (FAO 2012). Since the pesticide consumption databases cover only 21 years, the observed trends were categorized into only four groups: I-, N-, U-, and D-style. Developed and developing countries were classified according to the country classification of the World Economic Situation and Prospects (WESP) (United Nations 2012).

\subsection{Insecticide consumption}

The 82 countries consumed 342 thousand tonnes of insecticides in total per year on average from 1990 to 2010. The USA consumed the largest amount of insecticides with 90 thousand tonnes each year, followed by India (Table 1). Thirty-four countries used more than 1 thousand tonnes of insecticides each per year on average. Insecticide application rate, or the insecticide consumption per hectare of harvested area, varied among countries. Twenty countries consumed over $2 \mathrm{~kg} \mathrm{ha}^{-1}$ of insecticides in 2010, with 12 nations in North and South America (Fig. 3). Countries located at high latitudes, such as Norway and Denmark, consumed the least insecticides, using less than $45 \mathrm{~g} \mathrm{ha}^{-1}$ (Fig. 3). Twenty-nine countries (35.4\%) exhibited 


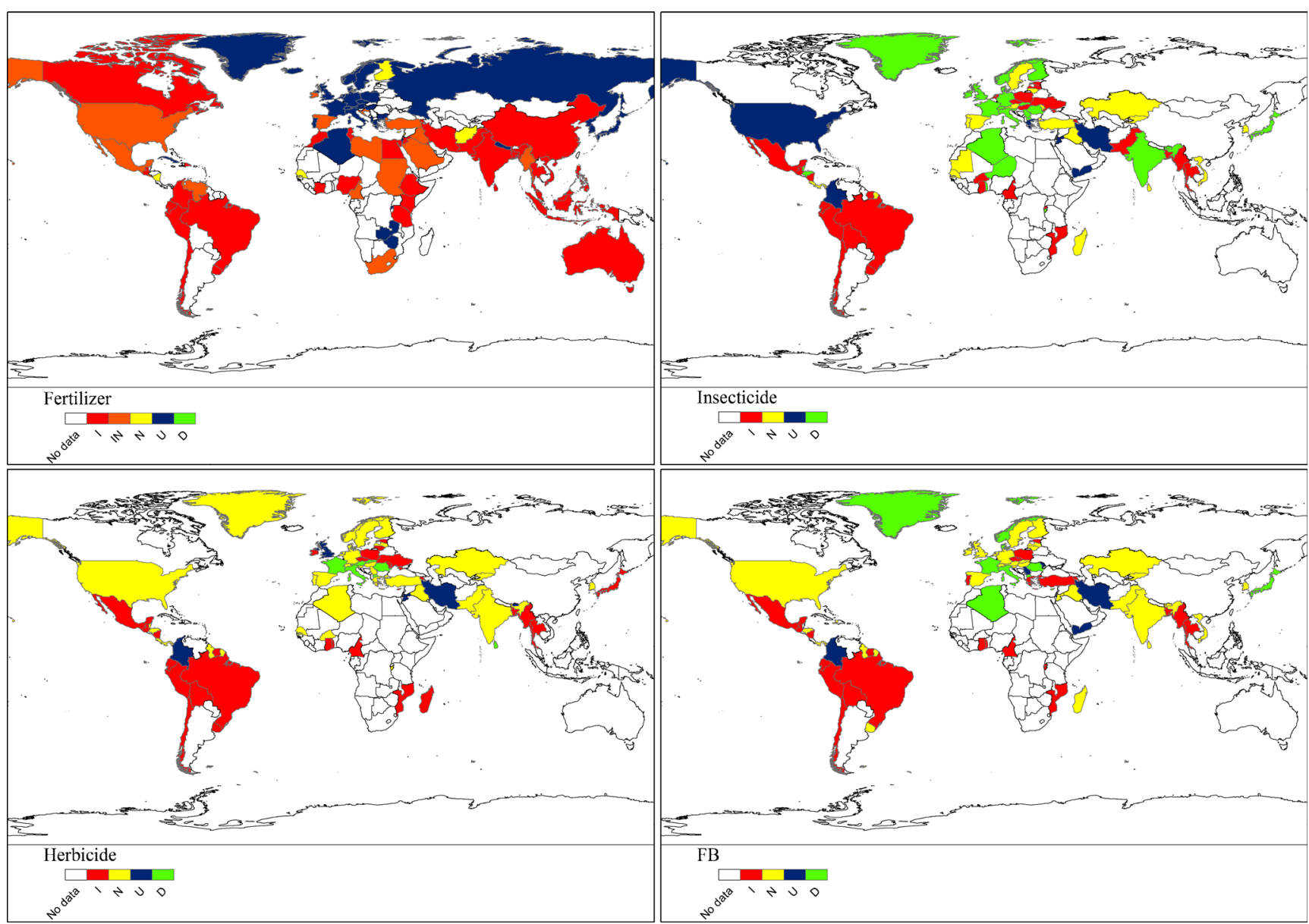

Fig. 4 Global maps of trend types for chemical additions (ArcMap 9.3, ESRI Inc.): top left, fertilizer trends from 1961 to 2010; top right, insecticide trends from 1990 to 2010; bottom left, herbicide trends from 1990 to 2010; bottom right, trends of fungicide and bactericide from 1990 to 2010

an I-style of insecticide consumption from 1990 to 2010 (Fig. 4; Table 2), including five developed countries (Czech Republic, Hungary, Latvia, Netherlands, and Poland). Most of these Istyle countries were situated in South America and Eastern Europe (Fig. 4). The insecticide consumption of 23 countries (28.1\%), including six developed countries, showed an N-style pattern. There were seven countries $(8.50 \%)$ that exhibited a unimodal trend (U-style). Twenty-three countries $(28.0 \%)$ displayed a decreased trend (D-style), of which over one half (13 countries) were developed nations in Europe (Fig. 4).

\subsection{Herbicide consumption}

The herbicide consumption of 75 countries per year was on average 566 thousand tonnes from 1990 to 2010. The USA consumed the most herbicides, at 201 thousand tonnes each year, followed by Mexico (Table 1). There were 45 countries which used more than 1 thousand tonnes of herbicides per year on average each. Most South American countries consumed over $2 \mathrm{~kg} \mathrm{ha}^{-1}$ of pesticides in 2010 (Fig. 3). South and West Asian countries such as India, Myanmar, and Bangladesh,

Table 2 Percentage of four trend types for consumption of fertilizers and pesticides (i.e., insecticides, herbicides, and fungicides and bactericides) and global cereal production at the country scale

\begin{tabular}{lllllll}
\hline Trend type $^{\mathrm{a}}$ & Cereal production (\%) & Yield (\%) & Fertilizers (\%) & Insecticides (\%) & Herbicides (\%) & Fungicides and bactericides (\%) \\
\hline Increase & 62.16 & 52.60 & 39.77 & 35.37 & 40.00 & 33.77 \\
No obvious trend & 17.57 & 24.00 & 7.95 & 28.05 & 44.00 & 48.05 \\
Increase then stagnate & 4.73 & 15.40 & 17.05 & - & - & - \\
Unimodal & 10.81 & 4.57 & 34.09 & 8.53 & 6.67 & 6.49 \\
Decrease & 4.73 & 3.43 & 1.14 & 28.05 & 9.33 & 11.69 \\
No. of countries & 148 & 175 & 88 & 82 & 75 & 77 \\
\hline
\end{tabular}

${ }^{\mathrm{a}}$ Trend type is consistent with Table 1 
consumed the least herbicides, using less than $100 \mathrm{~g} \mathrm{ha}^{-1}$ in 2010 (Fig. 3). Thirty countries $(40.0 \%)$ increased herbicide consumption (I-style) from 1990 to 2010 (Fig. 4; Table 2), including six developed countries. Most of these countries were situated in South America and in Eastern Europe. The herbicide consumption of 33 countries (44.0\%) was $\mathrm{N}$-style, and five countries ( $6.67 \%)$ exhibited U-styles, including one developed country (the UK). The remaining five developed and two developing countries (9.33\%), including Austria, France, Italy, Romania, Slovakia, Sri Lanka, and Macedonia, displayed a decreasing trend (D-style) (Fig. 4).

\subsection{Fungicide and bactericide consumption}

A total of 353 thousand tonnes of fungicides and bactericides were consumed per year on average across 77 countries. Italy consumed the most fungicides and bactericides (FB), using 61,700 tonnes each year, followed by France (Table 2). Fungicides and bactericides consumption per hectare of harvested area was also uneven worldwide. Most South American countries consumed around $1 \mathrm{~kg} \mathrm{ha}^{-1}$ of fungicides and bactericides in 2010, while Colombia used over $8 \mathrm{~kg}$ per hectare (Fig. 3). Ten countries in West Asia and Africa, such as Togo, Mozambique, Madagascar, Myanmar, Pakistan, and Iraq, consumed the least fungicides and bactericides, less than $70 \mathrm{~g} \mathrm{ha}^{-1}$ in 2010 (Fig. 3). There were 26 countries (33.8\%) which increased fungicides and bactericides consumption from 1990 to 2010 (I-style) (Fig. 4; Table 2), including four developed countries (Czech Republic, Greece, Poland, and Portugal). The fungicides and bactericides consumption of 37 countries (48.0\%) showed an N-style trend and included 15 developed countries. Five countries (Columbia, Iran, Moldova, Serbia and Montenegro, and Yemen) exhibited a U-style trend (6.50\%). Nine countries (11.7\%) displayed a D-style trend, and most of these (seven countries) were developed nations (Fig. 4).

While the use of agricultural chemicals for controlling pests can vastly improve crop yields, this comes with a cost to the environment. The impacts of chemical pesticides have come into focus since the publication of Rachel Carson's book Silent Spring in 1962. For example, exposing honey bees or bumblebees to pesticides has been shown to reduce the number of bee colonies, queen production, foraging success, and the rate of pollen collection (Gill et al. 2012; Henry et al. 2012; Whitehorn et al. 2012). Pesticides usually enter the soil via wash-off from treated foliage or are applied directly into soil to control pests and plant diseases. Pesticide application can undermine soil invertebrate population and soil quality (Goulson and Kleijn 2013; Muñoz-Leoz et al. 2013; Odukkathil and Vasudevan 2013; Pelosi et al. 2014). Pesticides can also be a threat to human health, for example when they appear as residues in food or drinking water. Farm workers and employees in the chemical industries may also be exposed to chemical pesticides (Goldman and Koduru 2000; Liang et al. 2012; Liu et al. 2012).
Countries showed a U- and D-style of chemical additions have started to find other solutions, besides chemicals, to control insects, weeds, and fungi for reducing the environmental impacts of chemical additions in agricultural systems. For example, "smart farming" technologies have resulted in reductions in inputs of chemical additions in the developed world, owing to accurate fertilizer placement and pesticide spraying, with navigation, sensor technology, data management, and farm management paving the way for high farming efficiency.

\section{History trend of global cereal yields and production}

Global yield and production of total cereals were downloaded from the FAOSTAT website (FAO 2012) to investigate trends from 1961 to 2010. One hundred and seventy-five countries with complete datasets were chosen for the analysis.

\subsection{Yield of total cereals}

Average cereal yields (over the last 50 years) varied from a low of $373 \mathrm{~kg} \mathrm{ha}^{-1}$ in Namibia to a high of $6,215 \mathrm{~kg} \mathrm{ha}^{-1}$ in the Netherlands across the 175 countries or regions under the study (FAO 2012). There were 38 countries that had average yields over 3,000 kg ha ${ }^{-1}$ (Fig. 5). The 20-fold variation in yield among countries indicates that solutions to increase cereal yields are needed, available, and feasible at the country-level. Countries with high yields were mainly situated in East Asia and North and South America, while most African countries produced low cereal yields (Fig. 5).

The average cereal yield of the 175 countries or regions during the last 50 years significantly increased from $1,358 \mathrm{~kg} \mathrm{ha}^{-1}$ in 1961 to $2,925 \mathrm{~kg} \mathrm{ha}^{-1}$ in 2010 ( $Y=$ $1,337.2+31.5 \times$ year, $\left.R^{2}=0.99\right)$. Ninety-two countries $(52.6 \%)$ had historically experienced yield increases, showing an I-style trend $\left(Y=1,246.7+45.7 \times\right.$ year, $\left.R^{2}=0.99\right)$ (Fig. 5; Table 2). Forty-two countries (24.0\%) showed interannual variation but no obvious trend $(\mathrm{N}$-style) in cereal yields. Cereal yields in 27 countries (15.4\%) first increased and then stagnated (IN-style). Eight countries (4.57\%) experienced yield collapses and showed a U-style, and six countries (3.43\%) had decreasing yields from 1961 onwards and showed D-styles (Fig. 5). Most of the N- and D-style countries were located in Africa.

\subsection{Production of total cereals}

Among the 148 countries or regions under study (FAO 2012), each of 30 countries produced more than 10 million tonnes of cereal per year on average. China had the highest cereal production, at 324 million tonnes each year, followed by USA (Table 1). Countries that had high cereal production 

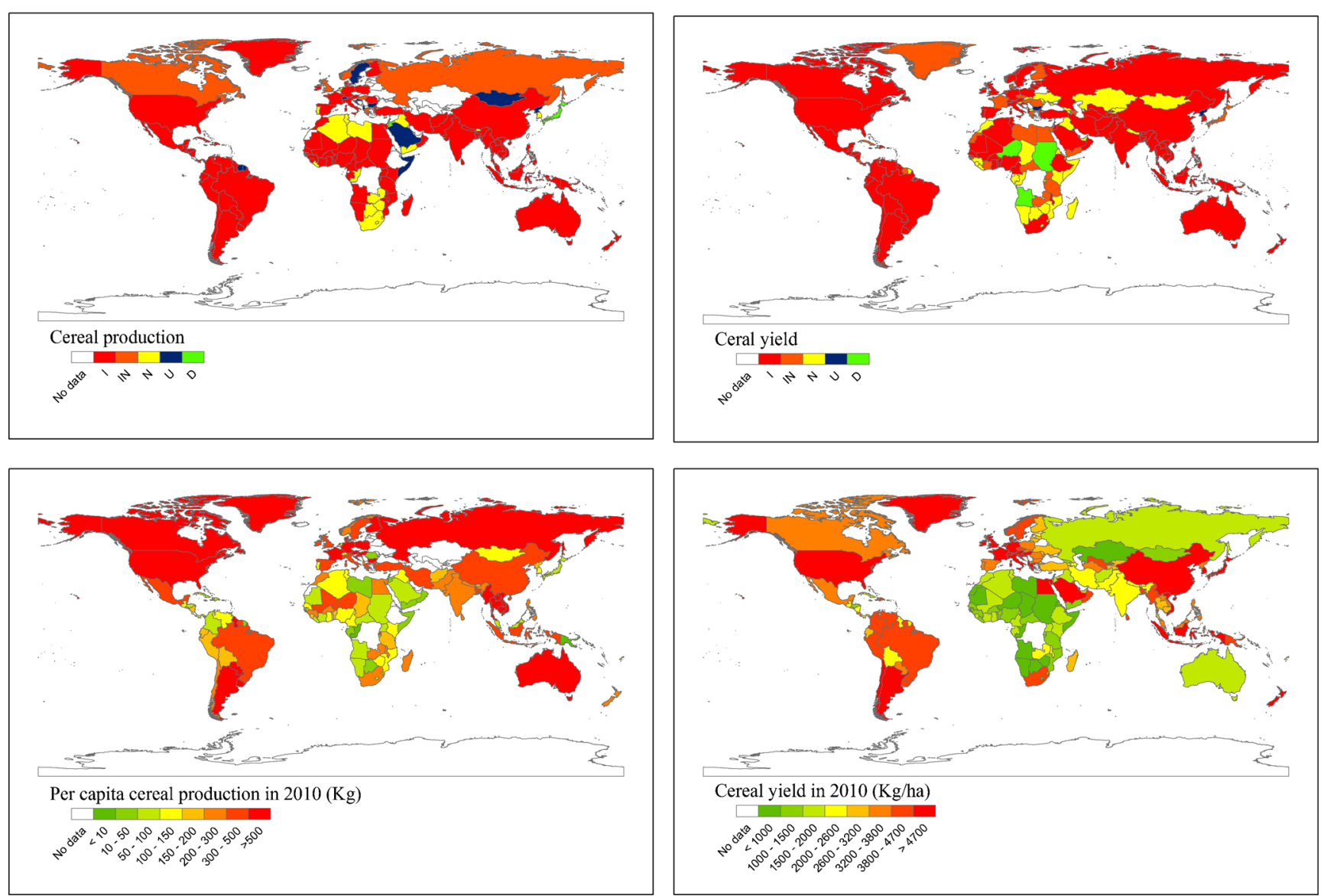

Fig. 5 Global maps of cereal production and yield (ArcMap 9.3, ESRI Inc.): five trend styles (I, IN, N, U, D) of cereal production (top left) and yield (top right) from 1961 to 2010, per capita cereal production (annual cereal production divided by population) in 2010 (bottom left), and cereal

per capita were mainly situated in Europe and in North America, while most African countries had low cereal production per capita of less than $50 \mathrm{~kg}$ cereal per capita on average in 2010 (Fig. 5).

Approximately $62.2 \%$ of countries (92) increased cereal production from 1961 to 2010 (I-style) (Figs. 5, 6; Table 2), including the three highest cereal producers: China, the USA, and India. There were seven countries (4.73\%), Norway, Congo, Greece, Hungary, UK, Canada, and USF (the USSR and the Russian Federation), classified as first increasing and then stagnating (IN-style). These countries first increased production until roughly 1990 and then stagnated (Figs. 5 and 6). There were 26 countries (17.6\%) that showed interannual variation in production but no obvious trend (N-style) (Figs. 5 and 6; Table 2). Apart from the Netherlands and Portugal, the other N-style countries were developing nations, and most of them were in Africa (Fig. 5). The mean gross domestic product (GDP) per capita in those countries $(2.97 \times$ $10^{3}$ dollars on average) was three times less than the mean value $\left(1.15 \times 10^{4}\right.$ dollars) in the world in 2010 (rude data from the World Bank). Cereal production in 16 countries (10.8\%)

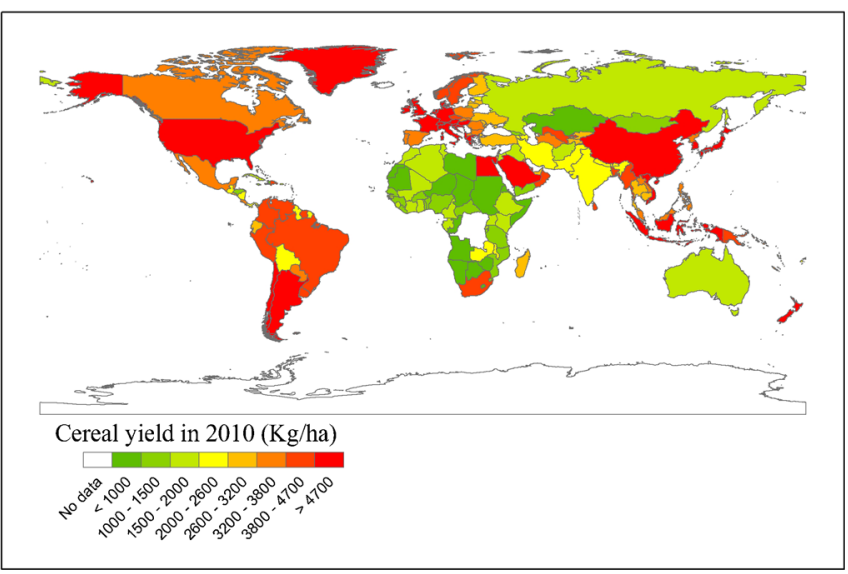

yield in 2010 (bottom right). I, IN, N, U, and D suggest increasing, stagnating, interannual variability, collapsing, and decreasing trends, respectively

first increased until 1985-1990 and then decreased, exhibiting a unimodal trend (U-style); this category included two developed countries, Sweden and Switzerland (Figs. 5 and 6; Table 2). This may indicate that the 1980s were boom years in cereal production for these countries. There were seven countries $(4.73 \%)$ that showed decreased production (D-style), including two developed countries (Cyprus and Japan) (Fig. 5).

The global imbalance in the consumption of fertilizers and pesticides inevitably has had impacts on cereal production around the world. Developed countries, such as those in Europe, have had high cereal production per capita, and yields and production have increased over time. In these countries, the amount of fertilizers and pesticides used has also been high.

In contrast, per capita cereal production in most African countries was very low (Fig. 5), and cereal yields either stayed the same or even decreased over time. Other studies have also found evidence for stagnation in yields in some regions (Peltonen-Sainio et al. 2009; Lin and Huybers 2012). For example, based on dataset for maize, rice, wheat, and soybean from 1961 to 2008, Ray et al. found that yields in around a quarter of cereal growing area either stagnated or declined (Ray

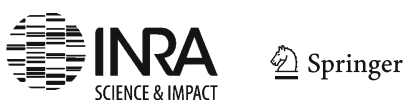



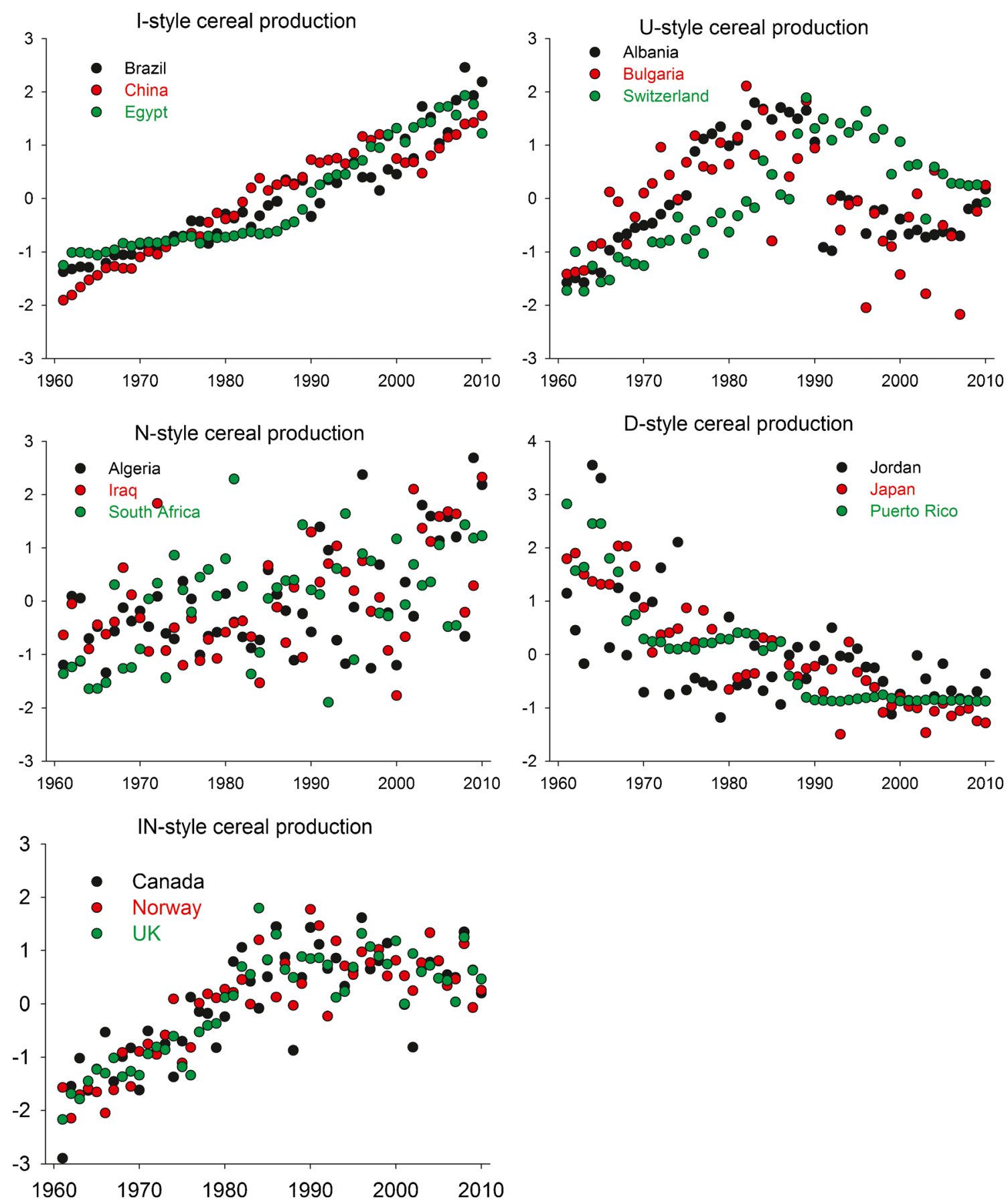

Fig. 6 Illustrative examples for five styles of global cereal production trends from 1961 to 2010: Filled points in each panel are the cereal production in three example countries

et al. 2012). Cereal yields mainly depend on the crop varieties grown and the environmental conditions (both abiotic and biotic) and the crop experiences, such as nutrient inputs, herbivory damage, competition from weeds, diseases, and local climate. Cereal yields and production in those $\mathrm{N}$-style countries depends on natural weather fluctuations, and here there is a lack of effective agricultural management policies, which may play an important role in improving cereal yields.

\section{Integrated assessment of chemical additions}

Per capita cereal production was calculated by dividing cereal production by population for each country studied in 2010 . The consumption of fertilizers and pesticides (insecticides, herbicides, fungicides, and bactericides) in 2010 was divided by harvested area to obtain the rate of fertilizer and pesticide application. All countries with data were ordered into the nine types and assigned values with integers from -4 to $4\left(X_{i}\right)$ for 
six indicators (i): per capita cereal production and yield, and fertilizer, insecticide, herbicide, and FB application rates. The weights of the six indicators $\left(W_{i}\right)$ were $0.4,0.2,0.1,0.1,0.1$, and 0.1 , respectively. The consumption index (CI) of each country was calculated as: $\mathrm{CI}=\sum_{i=1}^{6}\left(X_{i} \times W_{i}\right)$.

Low consumption index values mean that higher chemical additions are needed to increase cereal production, and high consumption index values indicate that chemical additions should be decreased to protect the environment. The six indicators were divided into two parts: the first included per capita cereal production and yield, and indicated the value of current cereal production, while the second part included the remaining four indicators and was a measure of environmental protection. When any indicator value was missing in either part, its weight was added to the other indicators in that part. The consumption index value will not be calculated if all indicators in any part were missing.

Countries with a high consumption index were mainly in North America, Europe, South and East Asia, and in the southern part of South America (Fig. 7), indicating that these countries should decrease the consumption of fertilizers and pesticides in agriculture systems for the health of their ecosystems. Countries in Africa had some of the lowest consumption index values, and West Asia and Russia also had low consumption indices. Policies in these countries, especially among the African countries, should strive to increase investment in nutrient additions to increase cereal production. It will be more efficient and effective to enhance the communication and cooperation between authorities and companies, particularly those producing fertilizer and pesticide.

If there are no feasible solutions to alleviate the negative effects of production practices aimed to simultaneously increase crop yields and decrease environmental impacts of agricultural intensification, there will be a trade-off between increased crop yield and environmental protection. Thus, feasible solutions should be developed to obtain a balance between increasing crop production to feed a growing human population and simultaneously mitigating negative environmental impacts (Tilman 2001; Foley et al. 2011; Mueller et al. 2012). For example, new technologies have gained high production with lower nutrient inputs (Matson et al. 1998). Drip and pivot techniques, conservation tillage, increased soil moisture capacities, and agro-forestry or tree-cropping systems are all technologies likely to increase nutrient-use efficiency and reduce environmental impacts. Biological pest control is an alternative method to control pests; the use of which may reduce pesticide consumption (Popp et al. 2013). Ecosystem-based methods for removing chemical pollutants, such as constructed wetlands, are an effective practice for mitigating hydrophobic pesticides in irrigation tailwater (Budd et al. 2009). When applying chemicals in a given

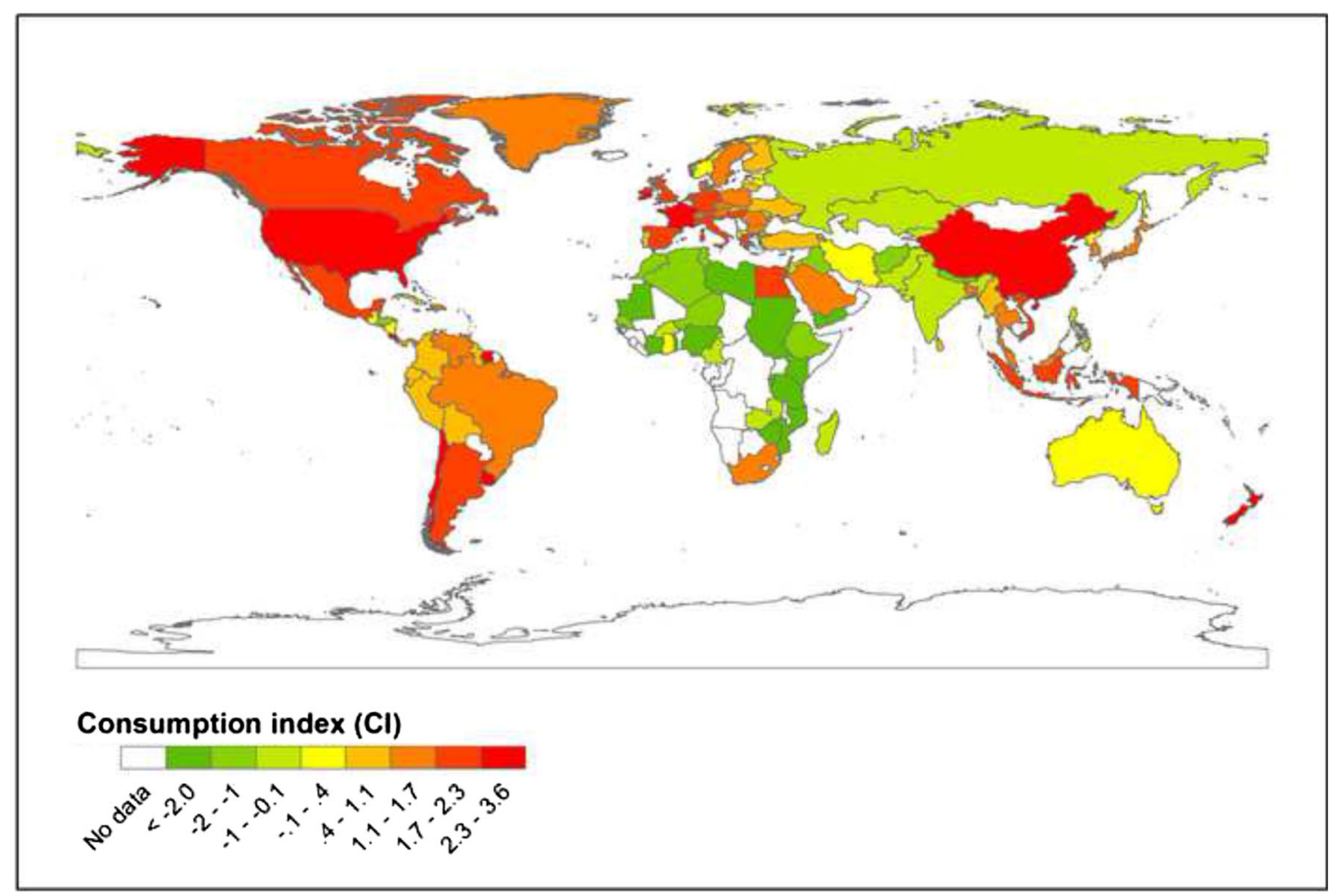

Fig. 7 Global maps of the consumption index (CI) for chemical additions (ArcMap 9.3, ESRI Inc.): integrated assessment for increasing (low CI value) or decreasing (high CI value) their consumption in each country 
location, it is also important to assess the agriculture ecosystem as one part of an integrated landscape, considering simultaneously the impacts of chemicals to be applied on the surrounding environment and on public health.

Besides the environment and public health effects of increased chemical use (Liu et al. 2012), additional factors are acting to increase pressure on global food supply, such as a decrease in area used for agriculture (Foley et al. 2011), the continual expansion of biofuel production (Gelfand et al. 2013), and the effects of climate change on cereal yield (Tao et al. 2012). Climate change has impacts on crop production generally through changing (1) the length of potential growing season for crops (Piao et al. 2006), (2) the geographic ranges of pests and diseases (Piao et al. 2010), (3) the frequency of extreme events, like droughts and floods (Dai et al. 2004; Pan et al. 2011), and (4) the fertilization of elevated $\mathrm{CO}_{2}$ and damaging effects of $\mathrm{O}_{3}$ (Fuhrer 2003; Long et al. 2005). In addition, the effects of climate change on crop production depend on regional conditions and crop varieties. For example, warming is likely to benefit irrigated agriculture but do harm to rainfed crops in China (Wang et al. 2009). The losses of wheat and rice can be avoided through changing crop varieties, planting time, fertilizer use, and irrigation, whereas such methods have little benefit for maize yield (Challinor et al. 2014). Thus, it is also important to consider the impacts of other factors on crop production in the integrated assessment and policymaking of chemical additions.

\section{Conclusions}

The global imbalance in the use of agricultural chemicals is responsible in part for the imbalance in the global food supply and environmental consequences. Most countries in Africa and Western Asia, and particularly African countries with low per capita food supplies, need to continue to increase their use of chemicals in order for crop production to feed their increasing populations. In contrast, many countries in Europe, North and South America, and Eastern Asia need to decrease their use of chemical additions in order to protect the environment and human health. The global imbalance in chemical applications and cereal production becomes a challenge in creating policies to balance food supply and environmental protection. This suggests that the policies should be based on nation or regional level because currently around one billion people still go hungry due to their inability to afford food instead of the lack of total food in the world. Thus, the consumption of chemical fertilizers and pesticides should be optimized across a far more complex landscape of production, environmental protection, and economic development.
Acknowledgments This work was supported by the National Environmental Protection Public Welfare Science and Technology Research Program (201309038), the Special Program for New Transgenic Variety Breeding of the Ministry of Science and Technology (2012ZX08011002), and the Natural Science Foundation of China (31200288).

\section{References}

Beketov MA, Kefford BJ, Schäfer RB, Liessa M (2013) Pesticides reduce regional biodiversity of stream invertebrates. Proc Natl Acad Sci U S A 110:11039-11043. doi:10.1073/pnas.1305618110

Budd R, O'Geen A, Goh KS, Bondarenko S, Gan J (2009) Efficacy of constructed wetlands in pesticide removal from tailwaters in the central valley. California Environ Sci Technol 43:2925-2930. doi: 10.1021/es802958q

Carpenter SR, Caraco NF, Correll DL, Howarth RW, Sharpley AN, Smith VH, Loren M (1998) Nonpoint pollution of surface waters with phosphorus and nitrogen. Ecol Appl 8:559-568. doi:10.1890/10510761(1998)008[0559:NPOSWW]2.0.CO;2

Challinor AJ, Waston J, Lobell DB, Howden SM, Smith DR, Chhetri N (2014) A meta-analysis of crop yield under climate change and adaption. Nat Clim Change 4:287-291. doi:10.1038/nclimate2153

Dai AG, Trenberth KE, Qian TT (2004) A global dataset of Palmer Drought Severity Index for 1870-2002: relationship with soil moisture and effects of surface warming. J Hydrometeorol 5:1117-1130. doi:10.1175/JHM-386.1

Del Grosso SJ, Cavigelli MA (2012) Climate stabilization wedges revisited: can agricultural production and greenhouse-gas reduction goals be accomplished? Front Ecol Environ 10:571-578. doi:10. $1890 / 120058$

FAO (2010) The state of food insecurity in the world: addressing food insecurity in protracted crises. Food and Agriculture Organization of the United Nations (FAO), Rome.

FAO (2012) Food and Agriculture Organization of the United Nations. FAOSTAT homepage. Available at http://faostat3.fao.org/home. Accessed 6 Nov 2012

Foley JA, Ramankutty N, Brauman KA, Cassidy ES, Gerber JS, Johnston M, Mueller ND, O'Connell C, Ray DK, West PC, Balzer C, Bennett EM, Carpenter SR, Hill J, Monfreda C, Polasky S, Rockström J, Sheehan J, Siebert S, Tilman D, Zaks DPM (2011) Solutions for a cultivated planet. Nature 478:337-342. doi:10.1038/nature10452

Fuhrer J (2003) Agroecosystem responses to combinations of elevated $\mathrm{CO}_{2}$, ozone, and global climate change. Agric Ecosyst Environ 97: 1-20. doi:10.1016/S0167-8809(03)00125-7

Garratt MPD, Wright DJ, Leather SR (2011) The effects of farming system and fertilisers on pests and natural enemies: a synthesis of current research. Agric Ecosyst Environ 141:261-270. doi:10.1016/ j.agee.2011.03.014

Gelfand I, Sahajpal R, Zhang X, Izaurralde RC, Gross KL, Robertson GP (2013) Sustainable bioenergy production from marginal lands in the US Midwest. Nature 493:514-517. doi:10.1038/nature11811

Gill RJ, Ramos-Rodriguez O, Raine NE (2012) Combined pesticide exposure severely affects individual- and colony-level traits in bees. Nature 491:105-108. doi:10.1038/nature11585

Godfray HCJ, Beddington JR, Crute IR, Haddad L, Lawrence D, Muir JF, Pretty J, Robinson S, Thomas SM, Toulmin C (2010) Food security: the challenge of feeding 9 billion people. Science 327:812-818. doi: $10.1126 /$ science. 1185383

Goldman LR, Koduru S (2000) Chemicals in the environment and developmental toxicity to children: a public health and policy perspective. Environ Health Perspect 108:443-448 
Goulson D, Kleijn D (2013) REVIEW: an overview of the environmental risks posed by neonicotinoid insecticides. J Appl Ecol 50:977-987. doi:10.1111/1365-2664.12111

Graf R, Müller M, Korner P, Jenny M, Jenni L (2014) 20\% loss of unimproved farmland in 22 years in the Engadin, Swiss Alps. Agric Ecosyst Environ 185:48-58. doi:10.1016/j.agee.2013.12.009

Henry M, Beguin M, Requier F, Rollin O, Odoux J-F, Aupinel P, Aptel J, Tchamitchian S, Decourtye A (2012) A common pesticide decreases foraging success and survival in honey bees. Science 336:348-350. doi:10.1126/science. 1215039

Huang J, Wang X, Zhi H, Huang Z, Rozelle S (2011) Subsidies and distortions in China's agriculture: evidence from producer-level data. Aust J Agric Resour Econ 55:53-71. doi:10.1111/j.14678489.2010.00527.x

IFA (2012) International Fertilizer Industry Association. IFADATA homepage. Available at http://www.fertilizer.org/ifa/ifadata/search. Accessed 6 Nov 2012

Ju XT, Xing GX, Chen XP, Zhang SL, Zhang LJ, Liu XJ, Cui ZL, Yin B, Christie P, Zhu ZL, Zhang FS (2009) Reducing environmental risk by improving $\mathrm{N}$ management in intensive Chinese agricultural systems. Proc Natl Acad Sci U S A 106:3041-3046. doi:10.1073/ pnas.0813417106

Kuivila KM, Hladik ML, Ingersoll CG, Kemble NE, Moran PW, Calhoun DL, Nowell LH, Gilliom RJ (2012) Occurrence and potential sources of pyrethroid insecticides in stream sediments from seven U.S. metropolitan areas. Environ Sci Technol 46:4297-4303. doi: 10.1021/es2044882

Liang Y, Wang W, Shen Y, Liu Y, Liu XJ (2012) Effects of home preparation on organophosphorus pesticide residues in raw cucumber. Food Chem 133:636-640. doi:10.1016/j.foodchem.2012.01.016

Lin M, Huybers P (2012) Reckoning wheat yield trends. Environ Res Lett 7:024016. doi:10.1088/1748-9326/7/2/024016

Liu J, You L, Amini M, Obersteiner M, Herrero M, Zehnder AJB, Yang H (2010) A high-resolution assessment on global nitrogen flows in cropland. Proc Natl Acad Sci U S A 107:8035-8040. doi:10.1073/ pnas.0913658107

Liu Y, Liu F, Pan X, Li J (2012) Protecting the environment and public health from pesticides. Environ Sci Technol 46:5658-5659. doi:10. 1021/es301652v

Long SP, Ainsworth EA, Leakey ADB, Morgan PB (2005) Global food insecurity. Treatment of major food crops with elevated carbon dioxide or ozone under large-scale fully open-air conditions suggests recent models may have overestimated future yields. Phil Trans R Soc B 360:2011-2020. doi:10.1098/rstb.2005.1749

MacDonald GK, Bennett EM, Potter PA, Ramankutty N (2011) From the cover: agronomic phosphorus imbalances across the world's croplands. Proc Natl Acad Sci U S A 108:3086-3091. doi:10.1073/pnas. 1010808108

Martínez-Blanco J, Lazcano C, Christensen TH, Muñoz P, Rieradevall J, Møller J, Antón A, Boldrin A (2013) Compost benefits for agriculture evaluated by life cycle assessment. A review Agron Sustain Dev 33:721-732. doi:10.1007/s13593-013-0148-7

Matson PA, Parton WJ, Power AG, Swift M (1997) Agricultural intensification and ecosystem properties. Science 277:504-509. doi:10. 1126/science.277.5325.504

Matson PA, Naylor R, Ortiz-Monasterio I (1998) Integration of environmental, agronomic, and economic aspects of fertilizer management. Science 280:112-115. doi:10.1126/science.280.5360.112

Miao Y, Stewart BA, Zhang F (2011) Long-term experiments for sustainable nutrient management in China. A review Agron Sustain Dev 31:397-414. doi:10.1051/agro/2010034

Mueller ND, Gerber JS, Johnston M, Ray DK, Ramankutty N, Foley JA (2012) Closing yield gaps through nutrient and water management. Nature 490:254-257. doi:10.1038/nature11420

Muñoz-Leoz B, Garbisu C, Charcosset J-Y, Sánchez-Pérez JM, Antigüedad I, Ruiz-Romera E (2013) Non-target effects of three formulated pesticides on microbially-mediated processes in a clayloam soil. Sci Total Environ 449:345-354. doi:10.1016/j.scitotenv. 2013.01.079

Odukkathil G, Vasudevan N (2013) Toxicity and bioremediation of pesticides in agricultural soil. Rev Environ Sci Biotechnol 12:421444. doi:10.1007/s11157-013-9320-4

Omuto C, Nachtergaele F, Rojas RV (2013) State of the art report on global and regional soil information: Where are we? Where to go? Global Soil Partnership Technical Report. Food and Agriculture Organization of the United Nations, Rome

Pan X, Shen D, Dong X, Patton B (2011) Natural disaster occurrence and average global temperature. Disaster Adv 4:61-63

Pelosi C, Barot S, Capowiez Y, Hedde M, Vandenbulcke F (2014) Pesticides and earthworms. A review Agron Sustain Dev 34:199 228. doi:10.1007/s13593-013-0151-z

Peltonen-Sainio P, Jauhiainen L, Laurila IP (2009) Cereal yield trends in northern European conditions: changes in yield potential and its realization. Field Crops Res 110:85-90. doi:10.1016/j.fcr. 2008.07.007

Piao SL, Fang JY, Zhou LM, Ciais P, Zhu B (2006) Variations in satellitederived phenology in China's temperate vegetation. Global Change Biol 12:672-685. doi:10.1111/j.1365-2486.2006.01123.x

Piao S, Ciais P, Huang Y, Shen Z, Peng S, Li J, Zhou L, Liu H, Ma Y, Ding Y, Friedlingstein P, Liu C, Tan K, Yu Y, Zhang T, Fang J (2010) The impacts of climate change on water resources and agriculture in China. Nature 467:43-51. doi:10.1038/nature09364

Pingali PL (2012) Green Revolution: impacts, limits, and the path ahead. Proc Natl Acad Sci U S A 109:12302-12308. doi:10.1073/pnas. 0912953109

Popp J, Pető K, Nagy J (2013) Pesticide productivity and food security. A review Agron Sustain Dev 33:243-255. doi:10.1007/s13593-0120105-x

Ray DK, Ramankutty N, Mueller ND, West PC, Foley JA (2012) Recent patterns of crop yield growth and stagnation. Nat Commun. doi:10. 1038/ncomms 2296

Russell AE, Cambardella CA, Laird DA, Jaynes DB, Meek DW (2009) Nitrogen fertilizer effects on soil carbon balances in midwestern U.S. agricultural systems. Ecol Appl 19:1102-1113. doi:10.1890/07-1919.1

Sun B, Zhang LX, Yang LZ, Zhang FS, Norse D, Zhu ZL (2012) Agricultural non-point source pollution in China: causes and mitigation measures. Ambio 41:370-379. doi:10.1007/s13280-012-0249-6

Tao F, Zhang Z, Zhang S, Zhu Z, Shi W (2012) Response of crop yields to climate trends since 1980 in China. Clim Res 54:233-247. doi:10. $3354 / \mathrm{cr} 01131$

Tilman D (2001) Forecasting agriculturally driven global environmental change. Science 292:281-284. doi:10.1126/science.1057544

Tilman D, Cassman KG, Matson PA, Naylor R, Polasky S (2002) Agricultural sustainability and intensive production practices. Nature 418:671-677. doi:10.1038/nature01014

United Nations (201) Country classification in: United Nations publication (Ed.) World Economic Situation and Prospects, New York, pp. 131-140.

Vitousek PM, Mooney HA, Lubchenco J, Melillo JM (1997) Human domination of Earth's ecosystems. Science 277. doi:10.1126/ science. 277.5325 .494

Vitousek PM, Naylor R, Crews T, David MB, Drinkwater LE, Holland E, Johnes PJ, Katzenberger J, Martinelli LA, Matson PA, Nziguheba G, Ojima D, Palm CA, Robertson GP, Sanchez PA, Townsend AR, Zhang FS (2009) Nutrient imbalances in agricultural development. Science 324:1519-1520. doi:10.1126/science.1170261

Wang JX, Mendelsohn R, Dinar A, Huang J, Rozelle S, Zhang L (2009) The impact of climate change on China's agriculture. Agric Econ 40:323-337. doi:10.1111/j.1574-0862.2009.00379.x

Whitehorn PR, O'Connor S, Wackers FL, Goulson D (2012) Neonicotinoid pesticide reduces bumble bee colony growth and queen production. Science 336:351-352. doi:10.1126/science. 1215025 